Available online at www.sciencescholar.us

Vol. 6 No. 1, April 2022, pages: 103-114

e-ISSN: 2550-696X, p-ISSN: 2550-6978

https://doi.org/10.53730/ijhs.v6n1.3390

\title{
Formation of Future Economist Professional Competence in Adaptive-digital Environment Conditions of Higher Educational Institution
}

\begin{abstract}
C. CrossMark
\end{abstract}
Liudmyla Sydoruk ${ }^{a}$, Nataliia Bakhmat ${ }^{b}$, Hanna Poberezhets ${ }^{c}$, Viktoria Misenyova ${ }^{d}$, Olena Boyarova $^{\mathrm{e}}$

Manuscript submitted: 27 August 2021, Manuscript revised: 9 November 2021, Accepted for publication: 29 December 2021

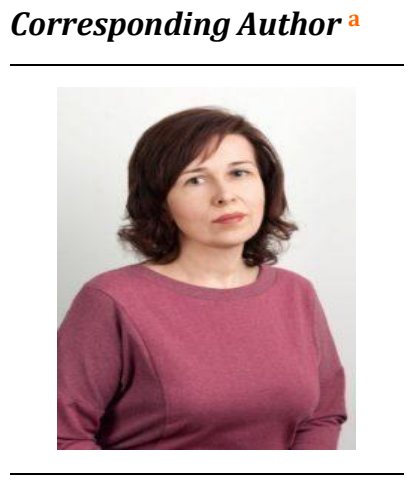

Keywords

digital environment; education program; education system; educational environment; educational materials;

higher education;

professional competence;

\begin{abstract}
The purpose of the academic paper lies in assessing the state of formation of future economists' professional competence within the conditions of the adaptive-digital environment of a higher educational institution. Methodology. The level of digitalization of higher educational institutions in Poland, the Czech Republic, Germany, and France has been assessed in the research. Based on the OECD database, the skills of specialists needed in the labor markets in different countries have been evaluated. Results. Within the countries, significant differences are observed in the level of digitalization, which will determine and influence the competence of a future specialist. The development of digital technologies in the HEI poses a threat and causes developing various groups of students - future economists' skills. In practical activities, an economist should possess highly developed technical, digital, and mathematical skills. The lack of critical thinking skills among specialists $(0,245$ in the Czech Republic and 0,255 in Germany) or active learning is particularly acute. This means that the development of this skill requires time, which is limited within the conditions of digitalization of higher education. The lack of social skills developing the professional competence of economists has been also observed in the Czech Republic, France, and Germany.
\end{abstract}

International Journal of Health Sciences (C) 2022. This is an open access article under the CC BY-NC-ND license (https://creativecommons.org/licenses/by-nc-nd/4.0/).

a Kamianets-Podilskyi National University, Kamianets-Podilskyi, Ukraine

b Kamianets-Podilskyi National Ivan Ohiienko University, Kamyanets-Podilsky, Ukraine

c Mykolayiv National Agricultural University, Mykolayiv, Ukraine

d National University of Life and Environmental Sciences of Ukraine, Kyiv, Ukraine

e Yaroslav Mudryi National Law University, Kharkiv, Ukraine 


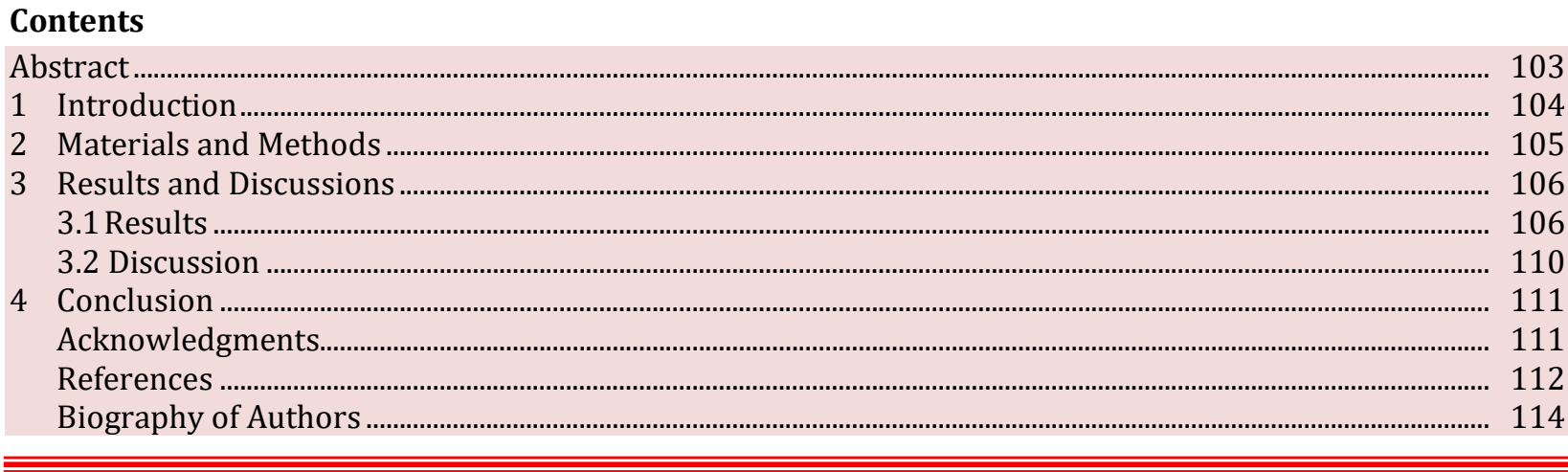

\section{Introduction}

In the context of the pandemic and the massive transition of higher educational institutions to distance training modes, students and teachers were obliged to adapt as quickly as possible to the new conditions of the educational environment. The new conditions provided for the complete digitization and application of technologies for studying educational materials, communication, evaluation, and monitoring of students by teachers. The education system has undergone radical digital transformations, which has significantly accelerated its digital development; however, it has had different consequences for the professional competence formation of future economists (Liubarets et al., 2021). The level of students' digital skills increased significantly, but skills were limited to the use of standard technologies in training (Zoom, Microsoft Teams, Skype, Viber, Moodle). At the same time, economists should develop a significantly higher level of digital competencies (for instance, mastery of $1 \mathrm{C}$ software for analytical work, workflow programs, analysis of financial statements, Excel functions for constructing financial models, and forecasting cash flows). In this context, the issue of the formation of future economists' professional competence within the conditions of the adaptive-digital environment of a higher educational institution is actualized (Zohdi, 2020; Howell \& Gordon, 2001). While, before spreading the pandemic, adaptive training systems had been at the stage of implementation and experimental study of their effectiveness, then during the pandemic the situation changed radically. During a pandemic, HEIs were to provide the rapid adaptation of students and teachers to a completely digital environment to achieve the professional development of future specialists (Lundberg \& Stearns, 2019; Widana et al., 2021).

The academic paper purpose lies in assessing the state of formation of future economists' professional competence within the conditions of the adaptive-digital environment of a higher educational institution. To achieve the purpose outlined, the tasks have been defined, namely:

- To analyze the digitalization level of higher educational institutions;

- To identify the skills necessary for economists in labor markets of different countries;

- To reveal the features of labor markets: challenges for employment of economists.

\section{Literature review}

In the scientific literature, the competence concept is defined as a complex integrated quality of personality for implementing certain activities, as a property that includes personal abilities, knowledge, skills, and individual styles of work for professional self-fulfillment (Van der Vleuten et al., 2010; Dalton et al., 2011). Competence can also be defined as the ability to solve specific problems, tasks in the daily work of a specialist in various activity areas using his abilities, knowledge, experience following the value system (Grinyova, 2014; Ernawati et al., 2022).

Professional competence is defined as a qualitative characteristic of the degree of a person's possession of his professional activity, including as follows: the level of awareness of motives, inducements for activity (motives, interests, needs, aspirations, value orientations, ideas about social roles); level of assessment of personal qualities, traits, qualities as a specialist (professional knowledge, skills, abilities, professionally 
significant qualities); the level of regulation of professional formation and growth taking into account the principles outlined. Thus, the competence of a specialist characterizes his qualifications, namely: knowledge obtained, skills, abilities, experience, work styles required in professional activities. In this interpretation, the concept is based on the ability of a specialist to apply the knowledge acquired during training to the subject of professional activity (Popp et al., 2010). In this context, it is worth considering the classification of types of competencies of ONET specialists, including "Abilities, knowledge types, skills, and work styles" (2021), and is used by the OECD (2021a) to assess the development requirements of specialists' different competencies in various countries, namely:

- Abilities: Enduring attributes of the individual that influence performance" (OECD, 2021a);

- Knowledge types: Organised sets of principles and facts applying in general domains" (OECD, 2021a);

- Skills: Developed capacities that facilitate learning or performance, including basic skills" (OECD, 2021a);

- Work styles: Personal characteristics that can affect how well someone performs a job" (OECD, 2021a).

In HEIs, the basic skills of a specialist (developed abilities contributing to the rapid mastering of knowledge by a student), inter-functional skills (developed abilities contributing to the performance of professional activities), knowledge (a set of principles and facts in general areas) are formed (ONET, 2021). In the scientific literature, the adaptability of the educational process means the use of ICT to provide flexibility, focus on personal interests and individual features (innate abilities, character traits) of the student. The adaptive educational environment of the HEI is understood as an innovative system of pedagogy of educational activity, built based on ICT, new pedagogical methods, teaching technologies, computer-oriented means, information, and resource provision to adapt the educational process to the potential and needs of students of higher educational institutions (Bakhmat \& Sidoruk, 2019).

The literature on the economist labor market mainly focuses on initial placement or job conditions across tenure lengths. Many studies show dependence between job outcomes and demographic characteristics (e.g., nationality, gender), academic and education characteristics (e.g., GRE scores, grades, research portfolio, and advisor reputation), and education program characteristics (e.g., the size and rank of a doctoral program) (Chen et al., 2013). Thus, the scientific literature examines the issues of professional competence, types of specialists' competencies, and types of specialists' skills that are formed in the process of studying in higher educational institutions, the concept of adaptability of the educational process (Martyniv et al., 2021). Along with this, there are no comprehensive studies on the formation of future economists' professional competence within the conditions of the adaptive-digital environment of the higher educational institution (Somitca \& Somitca, 2021; Mukhtar et al., 2022).

\section{Materials and Methods}

In the first part of the present research, the level of digitalization of higher educational institutions is assessed; that is, the level of implementation of ICT at HEIs, innovative training methods, and technologies in Poland, the Czech Republic, Germany, and France. Based on the indicators of innovation in education (technology, tools, or instruments) at HEIs of the indicated countries, the level of their adaptability, flexibility, differences in the level of digitalization of higher education were assessed as potential factors of influence on the formation of economists' professional competence (percentage of graduates that work in highly innovative environment and workplaces, share of graduates who participate introducing innovations).

In the second part of the present research, based on data from the OECD (2021b) Skills for Jobs Database, the skills of specialists needed in labor markets in different countries were assessed. Indicators of shortage (positive values from 0 to +1 ) / excess (negative values from -1 to 0 ) of specialists' skills in different countries in 2020 were used for the assessment, characterizing the level of balance in the specialists' competence. The following skill groups were assessed, namely: "1. Basic Skills (Content). 2. Basic Skills (Process). 3. Social Skills. 4. Complex Problem-Solving Skills. 5. Technical Skills. 6. Systems Skills. 7. Resource Management Skills" (OECD, 2021a).

Sydoruk, L., Bakhmat, N., Poberezhets, H., Misenyova, V., \& Boyarova, O. (2022). Formation of future economist professional competence in adaptive-digital environment conditions of higher educational institution. International Journal of Health Sciences, 6(1), 103-114. https://doi.org/10.53730/ijhs.v6n1.3390 
In the third part of the research, the features of labor markets (challenges for the employment of economists) were assessed based on qualitative indicators, namely: 1. Employment. 2. Hours worked. 3. Wages. 4. Underqualification. 5. Unemployment. The assessment was carried out to compare the knowledge gained by specialists in the training programs "Business and Management" in different countries and to identify the features of the labor market in the context of employment by profession (Diachenko et al., 2021). The OECD Skills for Jobs Database was used for evaluation (2021b).

\section{Results and Discussions}

\subsection{Results \\ Digitization of higher education institutions}

Within the conditions of an adaptive digital environment, higher educational institutions are forced to adapt to the training of specialists, despite the level of penetration of digital technologies in the educational institution (Claro et al., 2012; Ross \& Sennyey, 2008). The determining factor in the effectiveness of the formation of economists' professional competence, in this case, is the gained level of digitalization and the use of innovative tools, teaching aids (Illge \& Schwarze, 2009; Charness \& Kuhn, 2011). Traditionally, in higher educational institutions, the level of applying technologies as innovative ways of learning and teaching is higher compared to other levels of education (Table 1). However, there are significant differences in the level of digitization within countries, which will determine and affect the future specialist's competence. For instance, the Czech Republic and Poland have the highest level of technology application in higher education, compared to the OECD average of $49.9 \%$ (percentage of graduates working in highly innovative workplaces). At the same time, the Czech Republic also has a high level of students' involvement in the implementation of innovations in higher educational institutions - 55\%, compared to the average level of 40\% in OECD countries. In Poland, on the other hand, students play a much smaller role in the introduction of technology in education $(21,5 \%)$. By the way, a high level of technology penetration in higher education is also observed in France: $39 \%$ of students study in a highly innovative environment, and $43 \%$ play an active role in its formation (introduction of technologies, their use as a means of learning). In Germany, the lowest rates of technology use in the educational environment are revealed - $29 \%$ of students study in highly innovative workplaces, while $23,5 \%$ of students play a role in introducing innovation.

Table 1

Innovation in education (technology, tools, or instruments) in different countries in all levels of education and higher education, 2020

\begin{tabular}{lcccccc}
\hline $\begin{array}{c}\text { Innovation type: } \\
\text { technology, tools, or } \\
\text { instruments }\end{array}$ & $\begin{array}{c}\text { Share of graduates that } \\
\text { work in highly innovative } \\
\text { workplaces }\end{array}$ & $\begin{array}{c}\text { Share of graduates who } \\
\text { participate in innovation } \\
\text { introduction }\end{array}$ & $\begin{array}{c}\text { Share of graduates that } \\
\text { work in highly innovative } \\
\text { workplaces and participate } \\
\text { in innovation introduction }\end{array}$ \\
\cline { 2 - 7 } & $\begin{array}{c}\text { All levels of } \\
\text { education }\end{array}$ & $\begin{array}{c}\text { Higher } \\
\text { education }\end{array}$ & $\begin{array}{c}\text { All levels of } \\
\text { education }\end{array}$ & $\begin{array}{c}\text { Higher } \\
\text { education }\end{array}$ & $\begin{array}{c}\text { All levels of } \\
\text { education }\end{array}$ & $\begin{array}{c}\text { Higher } \\
\text { education }\end{array}$ \\
\hline Poland & 30,419 & 41,543 & 18,838 & 21,475 & 10,700 & 14,920 \\
The Czech Republic & 37,271 & 50,901 & 48,300 & 55,061 & 26,515 & 36,973 \\
Germany & 19,097 & 26,081 & 20,633 & 23,521 & 12,182 & 16,987 \\
France & 28,571 & 39,019 & 37,997 & 43,316 & 19,179 & 26,743 \\
\hline
\end{tabular}

In Germany, the level of using innovative knowledge and training methods at higher educational institutions is $60,1 \%$ (percentage of graduates who work in highly innovative workplaces), in particular, students participate in the formation of new knowledge and the use of new methods in 74,3\% of cases (share of graduates participate in innovation introduction). For comparison, in the Czech Republic, the figures are 49,8\% and 80,8\%; in Poland $-63,9 \%$ and 67,9\%; in France $-37,6 \%$ and 60,3\%, respectively.

Skills needed in labor markets in different countries 
The development of digital technologies in the HEI poses a threat and causes developing various groups of students - future economists' skills. In practical activities, the economist should possess highly developed technical, digital skills, mathematical skills (for instance, to calculate the cost of software, calculate logistics costs, generate estimates, collect and process analytical information, compare commercial offers of counterparties, analyze financial statements using software, etc.). Although these groups of skills can be developed in a digital environment due to the implementation and control of the corresponding tasks, their group discussion, many other skills remain under threat. For instance, the lack of critical thinking skills among specialists $(0,245$ in the Czech Republic and 0,255 in Germany) or active learning is particularly acute. Critical thinking develops only in the process of practical activity as the formation of the ability to make conscious decisions in the process of high-level operations based on various strategies. This means that the development of this skill requires time, which is limited in the context of the digitalization of higher education.

Table 2

Lack/excess of specialists' skills in different countries, 2020

\begin{tabular}{lcccc}
\hline Skills & The Czech Republic & France & Germany & Poland \\
\hline Basic Skills (Content) & 0,19 & 0,167 & 0,259 & 0,021 \\
Reading Comprehension & 0,239 & 0,173 & 0,32 & 0,009 \\
Active Listening & 0,19 & 0,167 & 0,279 & 0,004 \\
Writing & 0,205 & 0,182 & 0,3 & 0,042 \\
Speaking & 0,197 & 0,22 & 0,263 & 0,004 \\
Mathematics Skills & 0,17 & 0,109 & 0,235 & $-0,007$ \\
Science & 0,137 & 0,153 & 0,156 & 0,073 \\
Basic Skills (Process) & 0,205 & 0,211 & 0,228 & 0,042 \\
Critical Thinking & 0,245 & 0,166 & 0,255 & 0,036 \\
Active Learning & 0,226 & 0,189 & 0,268 & 0,041 \\
Learning Strategies & 0,155 & 0,308 & 0,223 & 0,081 \\
Monitoring & 0,192 & 0,181 & 0,165 & 0,009 \\
Social Skills & 0,107 & 0,158 & 0,228 & $-0,035$ \\
Social Perceptiveness & 0,118 & 0,152 & 0,225 & $-0,023$ \\
Coordination & 0,125 & 0,19 & 0,117 & $-0,045$ \\
Persuasion & 0,119 & 0,1 & 0,341 & $-0,029$ \\
Negotiation & 0,111 & 0,129 & 0,293 & $-0,063$ \\
Instructing & 0,116 & 0,259 & 0,219 & 0,066 \\
Service Orientation & 0,052 & 0,116 & 0,175 & $-0,117$ \\
\hline
\end{tabular}

Consequently, the lack of social skills forming the professional competence of economists, including persuasion and negotiation has been revealed in the Czech Republic, France, and Germany. The ability to reach an arrangement on the most favorable conditions for lending, insurance, concluding contracts with intermediaries, partners is an important practical task of economists, which is little practiced in the higher educational institutions, especially in the period of digitalization and mass transition to digital communications with the condition of the pandemic.

Table 3

Lack/excess of specialists' skills in different countries, 2020

\begin{tabular}{lcccc}
\hline Skills & $\begin{array}{c}\text { The Czech } \\
\text { Republic }\end{array}$ & France & Germany & Poland \\
\hline Complex Problem Solving Skills & 0,218 & 0,094 & 0,244 & 0,074 \\
Technical Skills & 0,121 & $-0,016$ & $-0,034$ & 0,091 \\
Operations Analysis & 0,208 & 0,058 & 0,242 & 0,087 \\
\hline
\end{tabular}

Sydoruk, L., Bakhmat, N., Poberezhets, H., Misenyova, V., \& Boyarova, O. (2022). Formation of future economist professional competence in adaptive-digital environment conditions of higher educational institution. International Journal of Health Sciences, 6(1), 103-114. https://doi.org/10.53730/ijhs.v6n1.3390 


\begin{tabular}{|c|c|c|c|c|}
\hline Technology Design & 0,11 & 0,014 & 0,103 & 0,067 \\
\hline Equipment Selection & 0,102 & $-0,027$ & $-0,052$ & 0,067 \\
\hline Installation & 0,074 & $-0,007$ & 0,024 & 0 \\
\hline Programming & 0,089 & $-0,049$ & 0,095 & 0,139 \\
\hline Operation Monitoring & 0,131 & 0,006 & $-0,167$ & 0,095 \\
\hline Operation and Control & 0,065 & $-0,052$ & $-0,236$ & 0,097 \\
\hline Equipment Maintenance & 0,108 & $-0,062$ & $-0,123$ & 0,117 \\
\hline Troubleshooting & 0,148 & $-0,01$ & $-0,101$ & 0,11 \\
\hline Repairing & 0,13 & $-0,042$ & $-0,079$ & 0,12 \\
\hline Quality Control Analysis & 0,169 & $-0,003$ & $-0,077$ & 0,108 \\
\hline Systems Skills & 0,219 & 0,133 & 0,263 & 0,084 \\
\hline Judgment and Decision Making & 0,226 & 0,143 & 0,247 & 0,046 \\
\hline Systems Analysis & 0,219 & 0,118 & 0,25 & 0,092 \\
\hline Systems Evaluation & 0,212 & 0,139 & 0,291 & 0,114 \\
\hline Resource Management Skills & 0,148 & 0,169 & 0,1 & $-0,039$ \\
\hline Time Management & 0,179 & 0,17 & 0,089 & $-0,026$ \\
\hline Management of Financial Resources & 0,144 & 0,124 & 0,104 & $-0,078$ \\
\hline Management of Material Resources & 0,119 & 0,144 & 0,062 & $-0,055$ \\
\hline Management of Personnel Resources & 0,148 & 0,238 & 0,145 & 0,002 \\
\hline
\end{tabular}

In general, students - future economists possess a sufficient level of knowledge in different markets, indicating the effectiveness of educational training programs, forasmuch as surveys on the lack/excess of knowledge indicate small fluctuations (Table 4).

Table 4

Knowledge on Economics needed for specialists in various sectors of the economy, 2020

\begin{tabular}{lcccccc}
\hline Country & $\begin{array}{c}\text { Agriculture, } \\
\text { Forestry and } \\
\text { Fishing }\end{array}$ & Manufacturing & Construction & $\begin{array}{c}\text { Information } \\
\text { and } \\
\text { Communication }\end{array}$ & $\begin{array}{c}\text { Transportation } \\
\text { and Storage }\end{array}$ & Average \\
\hline The Czech Republic & 0,033 & 0,037 & $-0,021$ & 0,079 & 0,034 & 0,0324 \\
France & 0,045 & 0,03 & 0,014 & 0,054 & 0,009 & 0,0304 \\
Germany & $-0,058$ & 0,028 & 0 & 0,059 & $-0,006$ & 0,0046 \\
Poland & 0,077 & $-0,029$ & $-0,088$ & 0,041 & $-0,023$ & $-0,0044$ \\
European Union & 0 & 0,021 & $-0,036$ & 0,066 & 0,012 & 0,0126 \\
OECD & 0,005 & 0,022 & $-0,016$ & 0,054 & 0,011 & 0,0152 \\
\hline
\end{tabular}

Features of labor markets: challenges for employment of economists

The labor market in different countries determines the demand for specialists - economists, features of employment, wages, employment status, the attractiveness of the profession, and specialists' professional competencies (abilities, knowledge, skills, and work style). Consequently, understanding the labor market is important in the context of forming the professional competence of future economists. Labour market requirements are determined by educational training programs (curricula). Along with this, the level of cooperation between the higher educational institution and the private sector can influence the financing of the HEI to integrate ICT into the educational environment, thus, determining the level of digitalization and adaptability (Mansor et al., 2012; Chui \& bin Ahmad, 2016).

For instance, in France, economists face difficulties in being employed only using the knowledge gained during their studies (Table 5). Difficulties arise due to the rapid growth of employment in this profession, the rapid replacement of insufficiently qualified personnel (that is, lack of knowledge and skills leads to rapid dismissal), and a low unemployment level. At the same time, the increase in the number of working hours is slower compared to other professions. In France, the wages of economists are also growing faster than in other professions. 
Table 5

Comparison of knowledge gained by specialists in the training programs "Business and Management" in different countries and the features of the labor market in the context of employment by profession

\begin{tabular}{|c|c|c|c|c|}
\hline Country & France & Germany & Poland & The Czech Republic \\
\hline $\begin{array}{l}\text { Features of the } \\
\text { labor market }\end{array}$ & $\begin{array}{l}\text { Hard-to-fill } \\
\text { occupations using } \\
\text { this skill }\end{array}$ & $\begin{array}{l}\text { Hard-to-fill } \\
\text { occupations using } \\
\text { this skill }\end{array}$ & $\begin{array}{l}\text { Easy-to-fill } \\
\text { occupations using } \\
\text { this skill }\end{array}$ & $\begin{array}{l}\text { Hard-to-fill } \\
\text { occupations using } \\
\text { this skill }\end{array}$ \\
\hline $\begin{array}{l}\text { Employment in } \\
\text { occupation }\end{array}$ & $\begin{array}{l}\text { Employment is } \\
\text { rising faster } \\
\text { then the average of } \\
\text { the country }\end{array}$ & $\begin{array}{l}\text { Employment is } \\
\text { rising } \\
\text { slower than the } \\
\text { average of the } \\
\text { country }\end{array}$ & $\begin{array}{l}\text { Employment is } \\
\text { rising faster } \\
\text { then the average } \\
\text { of the country }\end{array}$ & $\begin{array}{l}\text { Employment in this } \\
\text { occupation is } \\
\text { rising slower } \\
\text { then the average of } \\
\text { the country }\end{array}$ \\
\hline $\begin{array}{l}\text { Number of hours } \\
\text { worked }\end{array}$ & $\begin{array}{l}\text { Hours worked are } \\
\text { rising } \\
\text { slower than the } \\
\text { country average }\end{array}$ & $\begin{array}{l}\text { Hours worked are } \\
\text { rising } \\
\text { faster than the } \\
\text { country average }\end{array}$ & $\begin{array}{l}\text { Hours worked are } \\
\text { rising slower } \\
\text { then the country } \\
\text { average }\end{array}$ & $\begin{array}{l}\text { Hours worked are } \\
\text { rising slower } \\
\text { then the country } \\
\text { average }\end{array}$ \\
\hline $\begin{array}{l}\text { Salaries in } \\
\text { occupation }\end{array}$ & $\begin{array}{l}\text { Salaries are rising } \\
\text { faster than the } \\
\text { country average }\end{array}$ & $\begin{array}{l}\text { Salaries are } \\
\text { rising faster } \\
\text { then the country } \\
\text { average }\end{array}$ & $\begin{array}{l}\text { Salaries are } \\
\text { rising faster than } \\
\text { the country } \\
\text { average }\end{array}$ & $\begin{array}{l}\text { Salaries are } \\
\text { rising faster than } \\
\text { the country } \\
\text { average }\end{array}$ \\
\hline Underqualification & $\begin{array}{l}\text { The under-qualified } \\
\text { workers change } \\
\text { share is higher in this } \\
\text { occupation than the } \\
\text { country average }\end{array}$ & $\begin{array}{l}\text { The under- } \\
\text { qualified workers } \\
\text { change share } \\
\text { is lower in this } \\
\text { occupation than } \\
\text { the country } \\
\text { average }\end{array}$ & $\begin{array}{l}\text { The under- } \\
\text { qualified workers } \\
\text { change share } \\
\text { is lower in this } \\
\text { occupation than } \\
\text { the country } \\
\text { average }\end{array}$ & $\begin{array}{l}\text { The under- } \\
\text { qualified workers } \\
\text { change share } \\
\text { is higher in this } \\
\text { occupation than } \\
\text { the country } \\
\text { average }\end{array}$ \\
\hline Unemployment & $\begin{array}{l}\text { The labour market } \\
\text { for this vocation } \\
\text { is weaker than in the } \\
\text { average of the } \\
\text { country (the lower } \\
\text { unemployment rate) }\end{array}$ & $\begin{array}{l}\text { The labour market } \\
\text { for this vocation } \\
\text { is weaker than in } \\
\text { the average of the } \\
\text { country (the lower } \\
\text { unemployment } \\
\text { rate) }\end{array}$ & $\begin{array}{l}\text { The labour market } \\
\text { for this vocation } \\
\text { is weaker than in } \\
\text { the average of the } \\
\text { country (the lower } \\
\text { unemployment } \\
\text { rate) }\end{array}$ & $\begin{array}{l}\text { The labour market } \\
\text { for this vocation } \\
\text { is weaker than in } \\
\text { the average of the } \\
\text { country (the lower } \\
\text { unemployment } \\
\text { rate) }\end{array}$ \\
\hline
\end{tabular}

Source: OECD (2021b).

The labour market for the profession of "economist" in Germany is somewhat different from the labour market in France, in particular, due to the slow employment growth (this may mean a long search and selection of qualified personnel, other approaches to employment with employers), low share of change of low-skilled personnel (this may be due to the high level of qualification, and, consequently, high-quality training programs). At the same time, the labour markets of Germany and Spain are similar due to difficulties in being employed in this profession, increasing the number of working hours and wages, low unemployment. The labour market of Poland differs significantly from the labour markets of France and Germany, primarily, due to the ease of being employed in the position of an economist, that is, the absence of difficulties in finding a job. In Poland, a high level of employment and a low level of unemployment of economists is observed; that is, the profession is in demand. Considering the slow growth of the number of Polish economists' working hours, wages are growing faster than in other professions. In addition, the attractiveness of the profession is

Sydoruk, L., Bakhmat, N., Poberezhets, H., Misenyova, V., \& Boyarova, O. (2022). Formation of future economist professional competence in adaptive-digital environment conditions of higher educational institution. International Journal of Health Sciences, 6(1), 103-114. https://doi.org/10.53730/ijhs.v6n1.3390 
also connected with the low rate of change of low-skilled workers, which may mean a high level of training. Therefore, the profession of an economist is the most attractive among young people in Poland.

In the Czech Republic, as well as in Germany, it is difficult to be hired for the position of an economist, forasmuch as slow growth of employment with low unemployment is observed. This may mean longer search times for professionals. However, the high rate of replacement of low-skilled economists in the Czech Republic may be related to their insufficient qualifications. Both in Germany and the Czech Republic, the growth of economists' wages is rapid, while the number of working hours is slow.

\subsection{Discussions}

Every year, bachelors, masters, graduate students face macroeconomic risks in labour markets, varying in different countries (Oyer, 2006). Macroeconomic conditions as a tool for initial employment determine the quality and type of initial work of the economist and have a causal effect on the long-term performance of the job. Therefore, this research has revealed a low unemployment rate in the specialty "Business and Management"; however, graduates face difficulties in finding, accepting vacancies, and hiring. Better initial placement in the labour market after graduation from the HEI increases the productivity of the economist (Oyer, 2006). Higher productivity contributes to a higher level of job satisfaction, rapid formation of practical skills, and career growth of the specialist.

The investigation of the job satisfaction determinants for UK economists based on data on individual (demographic, productive, and work-related) characteristics and features of the workplace shows that the majority of professionals (men and women) are satisfied with the work obtained. Workplace features are the most significant professional satisfaction determinants, especially working in a cooperative and gender environment. The respondents have also noted the importance of the adaptive environment of the educational institution, which contributes to the formation of productive characteristics, and, accordingly, affects the satisfaction with the place of employment (Mumford \& Sechel, 2019). Feld et al. (2013), explore the determinants of life satisfaction of economists. The analysis is based on a professional survey, including academic economists' answers from European countries and abroad. Feld et al. (2013), have identified certain features of the professional position of economists influencing their well-being. Job satisfaction depends on the time devoted to the research. Negative determinants of impact are the lack of a full-time position, reducing the level of satisfaction, in particular, if the contract cannot be extended or expires shortly. The expected level of external pressure on specialists (that is, competence requirements) also does not affect the level of satisfaction. In the present research, we have also revealed significant pressure on economists in the context of labour market demands. However, this factor may be leveled by specialists, forasmuch as even at the beginning of admission to the specialty, applicants understand the high level of pressure.

In the scientific article of Mumford \& Sechel (2020), data on the determinants of remuneration and positions among academic economists in the UK are explored. Features related to individual productivity and job characteristics are important determinants of relative wages and career structure in this sector. Along with this, there is a significant incomprehensible gender payment gap, which requires adjusting the adaptive environment of the HEI to possible challenges for women - specialists. Men are much more likely to be employed in high-paying positions, where there are also significant payment gaps between the genders. Even though the nature of the gender pay gap has changed over the last two decades, the size of the gap has remained unchanged (Mumford \& Sechel, 2020).

Earlier empirical studies of the labour market of economists (for instance, Abbott \& Ali (2011), on the labour market of New Zealand, based on data obtained from the Department of Labor of New Zealand (DoL), census survey, and Ministry of Education (MES) have concluded the level of supply and demand of economists. Consequently, in the New Zealand market for economists, there are two distinctly different subcategories (academic and non-academic) with completely different professional competencies. Abbott \& Ali (2011), also argue that employment prospects have been good for non-academic economists in recent years, but less favorable for academic work. Graduates of economics also receive an acceptable salary compared to other graduates (Abbott \& Ali, 2011). The present research has also revealed the following tendency, namely: for instance, the attractiveness of a profession in Poland with an increase in wages, a low level of unemployment; the profession is in demand in Germany, in the Czech Republic due to the increase in the wages of economists. 
Chen et al. (2013), have analyzed the place, type of work among candidates of various programs in economics in the labour market (non-US citizens) and have concluded that abroad graduates gravitate towards employment in academic circles. Secondly, with the international students increasing presence in US doctoral programs, a new growing dimension of the labour market has been identified - the initial employment international perspective for new doctors of philosophy in economic training programs (Chen et al., 2013). This means that the pressure on professionals in the domestic labour market, which restricts employment, can be offset by employment in other markets, where there is a demand in different categories of economists.

\section{Conclusion}

Within the conditions of an adaptive digital environment, higher educational institutions are forced to adapt to the training of specialists, despite the level of penetration of digital technologies in the educational institution. In higher education, the level of applying technologies as innovative ways of learning, teaching is higher compared to other levels of education. Within the ambit of the countries, there are significant differences in the level of digitization, which will determine and influence the competence of the future specialist. The development of digital technologies in the HEIs threatens and causes the formation of various groups of skills of students - future economists. In practical activities, the economist should possess highly developed technical, digital skills, mathematical skills. The lack of critical thinking skills among specialists $(0,245$ in the Czech Republic and 0,255 in Germany) or active learning is particularly acute. This means that the development of this skill requires time, which is limited within the conditions of digitalization of higher education. The lack of social skills developing the professional competence of economists has been also observed in the Czech Republic, France, and Germany. In general, students - future economists possess a sufficient level of knowledge in different markets, indicating the effectiveness of educational training programs.

Acknowledgments

We are grateful to two anonymous reviewers for their valuable comments on the earlier version of this paper.

Sydoruk, L., Bakhmat, N., Poberezhets, H., Misenyova, V., \& Boyarova, O. (2022). Formation of future economist professional competence in adaptive-digital environment conditions of higher educational institution. International Journal of Health Sciences, 6(1), 103-114. https://doi.org/10.53730/ijhs.v6n1.3390 


\section{References}

Abbott, M., \& Ali, E. (2011). What happens after graduation?: The market for economists. New Zealand Journal of Employment Relations, 36(1), 52-64.

Bakhmat, N., \& Sidoruk, L. (2019). Formation of modern ideas about the adaptive educational environment of higher education institutions. Educational space of Ukraine, (15), 17-25.

Charness, G., \& Kuhn, P. (2011). Lab labor: What can labor economists learn from the lab?. Handbook of labor economics, 4, 229-330. https://doi.org/10.1016/S0169-7218(11)00409-6

Chen, J., Liu, Q., \& Billger, S. (2013). Where do new Ph. D. economists go? Recent evidence from initial labor market. Journal of Labor Research, 34(3), 312-338.

Chui, T. B., \& bin Ahmad, M. S. (2016). Evaluation of service quality of private higher education using service improvement matrix. Procedia-Social and Behavioral Sciences, 224, 132-140. https://doi.org/10.1016/j.sbspro.2016.05.417

Claro, M., Preiss, D. D., San Martín, E., Jara, I., Hinostroza, J. E., Valenzuela, S., ... \& Nussbaum, M. (2012). Assessment of 21st century ICT skills in Chile: Test design and results from high school level students. Computers \& Education, 59(3), 1042-1053. https://doi.org/10.1016/j.compedu.2012.04.004

Dalton, M., Davidson, M., \& Keating, J. (2011). The Assessment of Physiotherapy Practice (APP) is a valid measure of professional competence of physiotherapy students: a cross-sectional study with Rasch analysis. Journal of Physiotherapy, 57(4), 239-246. https://doi.org/10.1016/S1836-9553(11)70054-6

Diachenko, A., Vusyk, H., Bielova, Y., Shurdenko, M., \& Titenko, O. (2021). The educational role in COVID-19 terms of ethnodesign graphic function in higher education practical activities. International Journal of Health Sciences, 5(3), 584-593. https://doi.org/10.53730/ijhs.v5n3.2540

Ernawati, E., Baso, Y. S., Hidayanty, H., Syarif, S., Aminuddin, A., \& Bahar, B. (2022). The effects of anemia education using web-based she smart to improve knowledge, attitudes, and practice in adolescent girls. International Journal of Health \& Medical Sciences, 5(1), 44-49. https://doi.org/10.21744/ijhms.v5n1.1831

Feld, L. P., Necker, S., \& Frey, B. S. (2013). Happiness of economists (No. 13/7). Freiburger Diskussionspapiere zur Ordnungsökonomik.

Grinyova, V. M. (2014). On the relationship between the concepts of professionalism, professional culture, professional competence, training. Pedagogy and Psychology, (45), 74-84.

Howell, M. N., \& Gordon, T. J. (2001). Continuous action reinforcement learning automata and their application to adaptive digital filter design. Engineering Applications of Artificial Intelligence, 14(5), 549-561. https://doi.org/10.1016/S0952-1976(01)00034-3

Illge, L., \& Schwarze, R. (2009). A matter of opinion-How ecological and neoclassical environmental economists and think about sustainability and economics. Ecological Economics, 68(3), 594-604. https://doi.org/10.1016/j.ecolecon.2008.08.010

Liubarets, V., Bakhmat, N., Kurylo, L., Spitsyna, A., \& Biriukova, O. (2021). Formation of Transversal Competences of Future Economists in the Conditions of Digital Space. Studies of Applied Economics, 39(9).

Lundberg, S., \& Stearns, J. (2019). Women in economics: Stalled progress. Journal of Economic Perspectives, 33(1), 3-22.

Mansor, N. N. A., Chakraborty, A. R., Yin, T. K., \& Mahitapoglu, Z. (2012). Organizational factors influencing performance management system in higher educational institution of South East Asia. Procedia-Social and Behavioral Sciences, 40, 584-590. https://doi.org/10.1016/j.sbspro.2012.03.234

Martyniv, L., Sokolova, A., Kurinna, S., Kopeliuk, O., Sediuk, I., \& Khomova, O. (2021). The modern problems and prospects of music formation and art education development during COVID-19. International Journal of Health Sciences, 5(3), 670-680. https://doi.org/10.53730/ijhs.v5n3.2936

Mukhtar, A. U. S., Budu, B., Sanusi B, Y., Mappawere, N. A., \& Azniah, A. (2022). The effect of reproductive health education with multimedia video learning on the improvement of fluor albus prevention behavior young woman pathologist. International Journal of Health \& Medical Sciences, 5(1), 75-79. https://doi.org/10.21744/ijhms.v5n1.1841

Mumford, K., \& Sechel, C. (2019). Job satisfaction amongst academic economists in the UK. Economics Letters, 182, 55-58. https://doi.org/10.1016/j.econlet.2019.05.025

Mumford, K., \& Sechel, C. (2020). Pay and Job Rank among Academic Economists in the UK: Is Gender Relevant?. British Journal of Industrial Relations, 58(1), 82-113. 
Oyer, P. (2006). Initial labor market conditions and long-term outcomes for economists. Journal of Economic Perspectives, 20(3), 143-160.

Popp, J. S. H., Newton, D. J., Pittman, D., Danforth, D. M., \& Abdula, A. (2010). Comparison of factors influencing salaries of agricultural economics professionals in academic and federal employment (No. 1370-2016108699).

Ross, L., \& Sennyey, P. (2008). The library is dead, long live the library! The practice of academic librarianship and the digital revolution. The Journal of Academic Librarianship,34(2), 145-152. https://doi.org/10.1016/j.acalib.2007.12.006

Somitca, S., \& Somitca, A. (2021). Integration Of Future Economists In The Labor Market The Impact Of Technology On The Profession Of Economist. International Journal of Educational Theory and Practice, 3947.

Van der Vleuten, C. P. M., Schuwirth, L. W. T., Scheele, F., Driessen, E. W., \& Hodges, B. (2010). The assessment of professional competence: building blocks for theory development. Best practice \& research Clinical obstetrics \& gynaecology, 24(6), 703-719. https://doi.org/10.1016/j.bpobgyn.2010.04.001

Widana, I.K., Sumetri, N.W., Sutapa, I.K., Suryasa, W. (2021). Anthropometric measures for better cardiovascular and musculoskeletal health. Computer Applications in Engineering Education, 29(3), 550561. https://doi.org/10.1002/cae.22202

Zohdi, T. I. (2020). A machine-learning framework for rapid adaptive digital-twin based fire-propagation simulation in complex environments. Computer Methods in Applied Mechanics and Engineering, 363, 112907. https://doi.org/10.1016/j.cma.2020.112907

Sydoruk, L., Bakhmat, N., Poberezhets, H., Misenyova, V., \& Boyarova, O. (2022). Formation of future economist professional competence in adaptive-digital environment conditions of higher educational institution. International Journal of Health Sciences, 6(1), 103-114. https://doi.org/10.53730/ijhs.v6n1.3390 


\section{Biography of Authors}

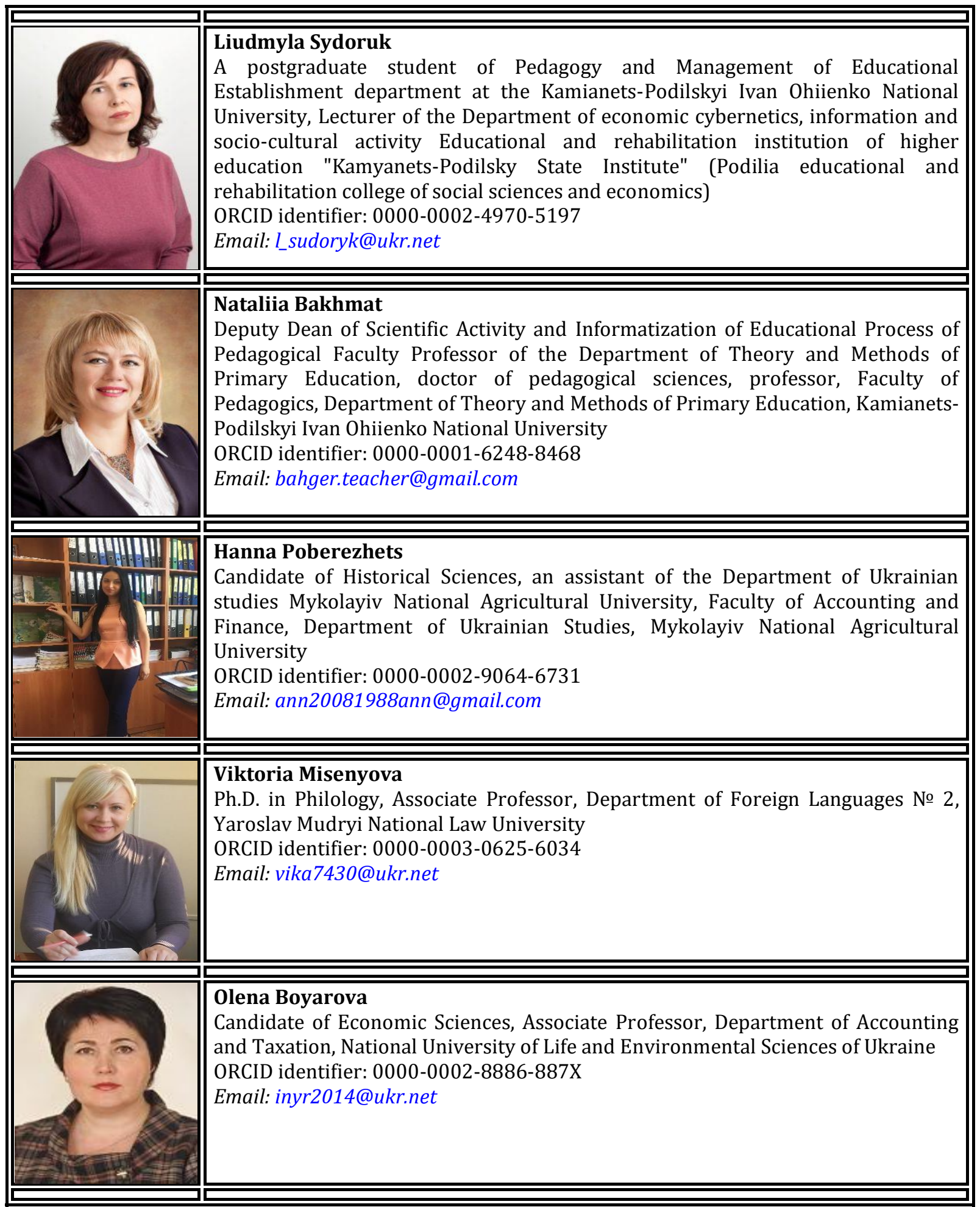

